\title{
Development of carpels and ovules in Dialypetalanthus fuscescens Kuhlm. (Rubiaceae): an enigmatic taxon
}

\author{
Rogério da Costa Figueiredo', Ricardo Cardoso Vieira², Jorge Ernesto de Araújo Mariath², \\ Maria Cecilia de Chiara Moço ${ }^{3}$ and Karen L. G. De Toni $4^{*}$
}

Received: December 20, 2016

Accepted: February 22, 2017

\begin{abstract}
Dialypetalanthus is a monospecific genus that occurs in the Amazon Basin of Brazil, Bolivia and Peru and occupies a controversial position among the Rubiaceae. We continue this taxonomic discussion with the overall aim of clarifying the systematic position of $D$. fuscescens within the Rubiaceae. To accomplish this, we analyzed the ontogeny of its gynoecium, in particular the floral meristem, as well as the development of the carpels and cauline placentation. Gynosporogenesis and the differentiation of the carpellary septa and ovules were also described. Dialypetalanthus fuscescens was classified according to evolutionary diagrams found in the literature. The following characteristics were observed in $D$. fuscescens: 1 ) permanence of the floral meristem in the central basal part of the early flower bud; 2) dual origin of carpellary septum; 3) trizonate ovular primordia with only one fertile gynospore per ovule; and 4) cellular proliferation in the chalazal region. Embryological results confirm the classification of $D$. fuscescens in the subfamily Ixoroideae. These results are distinct from any others previously proposed in the evolutionary diagram. Therefore, we conclude that this study has presented evidence strongly suggesting that Dialypetalanthus possesses new morphological-type of ovule we refer to as the Dialypetalanthus-type.
\end{abstract}

Keywords: carpel development, carpellary septum, cauline placentation, floral meristem, ovule

\section{Introduction}

The monospecific genus Dialypetalanthus is restricted to the boundaries of the Amazon Basin within Brazil, Bolivia and Peru. Historically, vegetative and reproductive characters, such as leaves, stipules, ovules, seeds, embryos, and fruits, led Kuhlmann (1925) to conclude that this taxon belongs to the family Rubiaceae with its circumscription in the tribe
Cinchoneae, subfamily Cinchonoideae (sensu Schumann 1891). The presence of free petals and several stamens, both uncommon characteristics among the Rubiaceae, allowed Kuhlmann (1942) to establish a new monogeneric tribe in the family: Dialypetalantheae. Based on anatomical analyses of leaf and wood, Rizzini \& Occhioni (1949) then gave the tribe Dialypetalantheae (sensu Kuhlmann 1942) family status, creating the Dialypetalanthaceae. According to these authors, this new family was closely related to Myrtaceae

\footnotetext{
${ }^{1}$ Programa de Pós-Graduação em Botânica do Museu Nacional, Universidade Federal do Rio de Janeiro, Quinta da Boa Vista s/n, 20940-040, Rio de Janeiro, RJ, Brazil

${ }^{2}$ Laboratório de Morfologia Vegetal, Departamento de Botânica, Universidade Federal do Rio de Janeiro, Av. Brigadeiro Trompowsky s.n., 21941590, Rio de Janeiro, RJ, Brazil

${ }^{3}$ Laboratório de Anatomia Vegetal, Departamento de Botânica, Instituto de Biociências, Universidade Federal do Rio Grande do Sul, Campus do Vale, Av. Bento Gonçalves, 9.500, Agronomia, 91501-970, Porto Alegre, RS, Brazil

${ }^{4}$ Laboratório de Botânica Estrutural, Diretoria de Pesquisa Científica, Instituto de Pesquisas Jardim Botânico do Rio de Janeiro, Rua Pacheco Leão 915, 22460-030, Rio de Janeiro, RJ, Brazil
}

* Corresponding author: karen.detoni@gmail.com 
and Melastomataceae. Cronquist (1968), Melquior (1964), Stebbins (1974), and Wagenitz (1992) all followed the hypothesis of Rizzini \& Ochioni (1949).

In his taxonomic revision of Rubiaceae, Robbrecht (1993) established common characters between Dialypetalanthus and Rubiaceae, such as thickening of the tangential wall of the exotesta cells, the presence of colleters in the internal region of the stipules, and absence of internal phloem. Nonetheless, this author emphasized that further studies on the morphology of this taxonomic group would be needed in order to resolve its systematic position.

Piesschaert et al. (1997) then described the following taxonomic features of $D$. fuscescens as having the presence of unitegmic ovules, a nectariferous disk covered by unicellular trichomes, exotestal seeds, and a well-developed endosperm. These characters suggested to the authors that Dialypetalanthus was unrelated to Myrtales. Instead, Piesschaert and coworkers believed that the structures of gynoecium, fruit, and seed all presented close similarities with those of Rubiaceae and, more specifically, with those of the subfamily Cinchonoideae. The presence of free petals and two series of several stamens, which is common in Myrtales, would be unique in Rubiaceae. However, these possible plesiomorphic characteristics would keep this taxon in an isolated position in the family. Despite this profound morphological analysis, Piesschaert et al. (1997) still insisted that phytochemical, ontogenetic, and macromolecular studies should be conducted in order to resolve the circumscription of Dialypetalanthus.

Indeed, molecular studies carried out by Fay et al. (2000) recommended the circumscription of this taxon in the subfamily Ixoroideae and the monotypic tribe Dialypetalantheae. More recently, molecular data from other studies have corroborated the position of $D$. fuscescens in the subfamily Ixoroideae, albeit changing the taxon to the tribe Condamineeae (Bremer \& Eriksson 2009; Kainulainen et al. 2010).

In the past and more recently, embryological descriptions have been successfully used in phylogenetic analysis to elucidate taxonomic relationships. For example, Fagerlind (1937), Andronova (1977), Galati (1991), Mariath \& Cocucci (1997), De Toni \& Mariath (2008; 2010), and Figueiredo et al. (2013a; b) have all reported variations in Rubiaceae ovules that suggest evolutionary tendencies. These studies highlighted morphological characters in the phylogeny of the groups, including reduction and disappearance of the external integument, inclusion of nucellus in the chalaza, flattening of the surface of the nucellar epidermis, elongation and reduction in the number of archesporial cells, and reduction in the number of meristematic layers. In the most recent studies, Figueiredo et al. (2013a; b) proposed new embryological characters for analysis, such as placenta position and origin of the carpellary septa. These embryological analyses have corroborated molecular phylogenies of Rubiaceae (De Toni \& Mariath 2010).
The present study described the gynosporogenesis of Dialypetalanthus fuscescens Kuhlm. and analyzed the ontogeny of its carpels, focusing on floral meristem, origin of carpellary septa and ovules. It was anticipated that such analysis would bring more consensus to the discussion of this species in relation to Rubiaceae, as well as classify it according to the current evolutionary hypotheses for the family in the context of its relationship with other taxa of Ixoroideae.

\section{Materials and methods}

We collected flower buds and flowers of Dialypetalanthus fuscescens Kuhlm. at different developmental stages in the arboretum of the Instituto de Pesquisas Jardim Botânico do Rio de Janeiro, Brazil (Fig. 1A-C). We deposited a voucher (RB 462363) of the collected material in the RB Herbarium.

The samples were fixed in $2.5 \%$ glutaraldehyde in $0.1 \mathrm{M}$ sodium phosphate buffer at $\mathrm{pH} 7.2$ (Gabriel 1982), dehydrated in ethanol series, and embedded in hydroxyethylmethacrylate (Gerrits \& Smid 1983). Sections 2-3 $\mu \mathrm{m}$ in thickness were obtained using a Shandom Hypercut rotary microtome equipped with a Leica D profile steel blade. The sections were stained with toluidine blue $0.05 \%$ (O’Brien et al. 1965). For observation under fluorescence microscopy, the sections were stained with aniline blue 0.5 \% (Oparka \& Read 1994). Observations and images were made using an Olympus BX-50 optical microscope coupled with a CoolSnap Pro digital camera.

\section{Results}

Dialypetalanthus fuscescens has a bicarpellate gynoecium and bilocular, inferior ovary, with a pluriovulated placenta per locule (Fig. 1C). The ovules are anatropous, unitegmic and tenuinucellated at maturity. At early developmental stages of flower bud growth, after the establishment of the calyx, corolla, and androecium, we observed the establishment of the gynoecium (Fig. 2A). A shallow central depression was observed in the floral bud owing to intercalary growth of the hypanthium (Fig. 2A). The carpel walls are established from two protuberances projected onto the still active floral meristem, initiating enclosure of the carpels (Fig. 2B). After enclosure of carpels, the margins of the carpel walls show an intensive mitotic division. Two emergent structures were observed to grow in two directions, first toward the floral apex, forming the style and stigma (Fig. 2C), and another toward the bottom of the flower bud, characterizing the apical portion of the carpellary septum (Fig. 2C-D).

The derivative cells of the consumed floral meristem localized in the central basal portion of the floral bud continues with a cellular proliferation in the central portion of the gynoecium. Besides this, we observed a cellular proliferation in the gynoecium region, which pushes the 


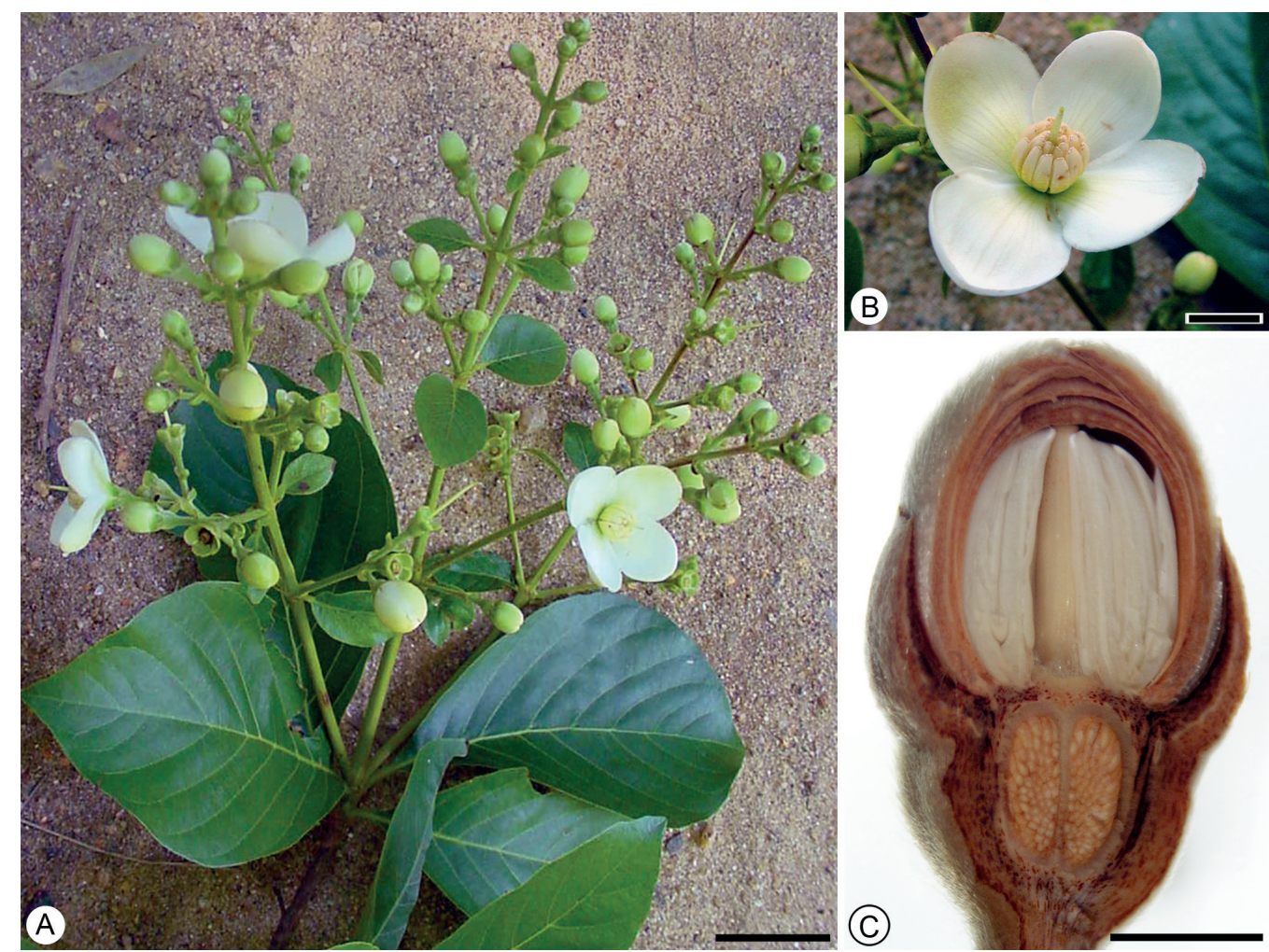

Figure 1. Flowers from Dialypetalanthus fuscescens Kuhlm. A. Flowering branch collected in the Arboretum of the Rio de Janeiro Botanical Garden. B. Flower detail, showing the inferior ovary and the pluriovulate placenta. C. Longitudinal section of a flower bud in a stereomicroscope. Scale bar $=5 \mathrm{~cm}$ in $\mathrm{A} ; 1.5 \mathrm{~cm}$ in $\mathrm{B}$, and $0.25 \mathrm{~cm}$ in $\mathrm{C}$.

derivatives meristematic cells mentioned above through the locule. This structure, termed placental column, acts like the basal septum (Fig. 2C-D); hence, the carpellary septum has a dual origin. One is apical, and it derives from the carpellary walls, while the other is basal, and it derives directly from the placental column (Fig. 2D).

When the apical portion of the carpellary septum, as shown in Figure $2 \mathrm{C}$, reaches the placental region, we observed the effective delimitation of two locules (Fig. 2D). Then, at the end of the development of the carpels, Dialypetalanthus fuscescens showed a complete fusion between the apical and basal portions of the septum.

After the delimitation of locules, derivatives meristematic cells are recognized as the placenta, and we observed the presence of numerous ovular primordia. The ovular primordia (Fig. 2E) were organized in three meristematic layers: dermal, subdermal, and central. Antiand periclinal divisions of the central layer subsequently formed ovules, while the dermal and subdermal layers grew through anticlinal divisions. Then, in the dermal layer, periclinal cell divisions were observed, resulting in a single integument (Fig. 2F). Subsequent divisions, both anticlinal and periclinal, in different proportions between the dorsal and ventral faces, generated significant asymmetry in ovule conformation, established initially as hemitropous (Fig. $2 \mathrm{~F}-\mathrm{G}$ ), but anatropous when mature.
The dermal layer takes part in the formation of the integument and the nucellar epidermis. This single layer was delimited by the integument, i.e., by the first divisions that established it. Integument growth and differentiation of the subdermal initials resulted in a dome-shaped nucellar epidermis (Fig. 2F-G), which arose at the earliest developmental stages.

Along with the development of the nucellar epidermis and integument, we observed a differentiation of cells adjacent to the nucellar epidermis in the subdermal layer, about three to four cells. These cells, termed subdermal initials (Fig. 2F), mature like the gynospore mother cells (Fig. 2G-H), and out of three, only one began meiosis after maturation.

Dyad formation occurred during gynosporogenesis after meiosis I (Fig. 2I-J), and after meiosis II, a linear tetrad was formed (Fig. 2K-L). The gynospores that formed were impregnated by callose (Fig. 2L), but in the chalazal gynospore, callose was located only in the distal periclinal cell wall, and it was this gynospore that remained viable.

In parallel with gynosporogenesis and gynogametogenesis, integument installation was derived from cell divisions of the epidermal layer. After maturation of the ovule, the single integument was massive (Fig. 2I). Besides the integument, we also observed another cellular 


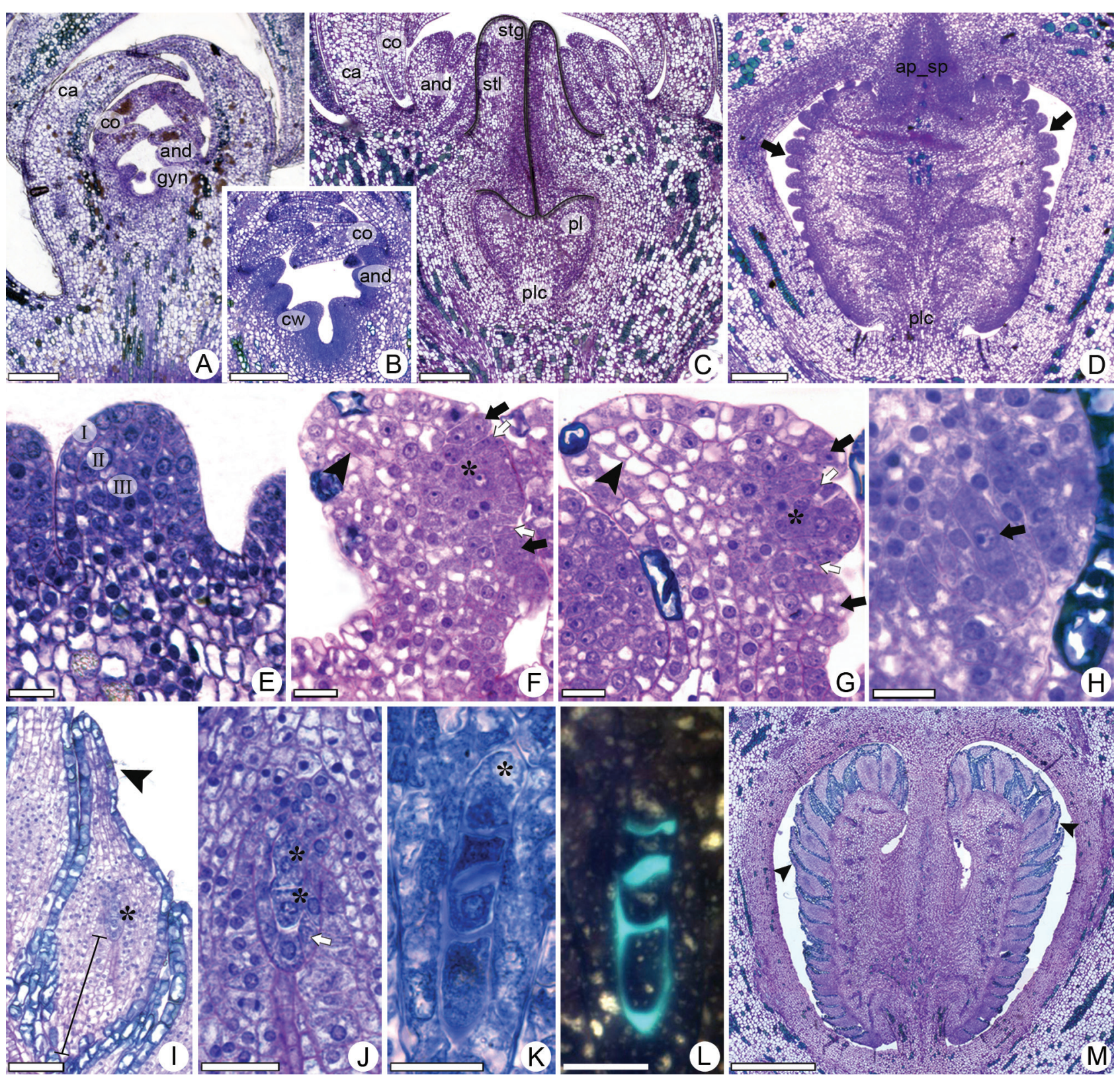

Figure 2. Carpel and ovule development in Dialypetalanthus fuscescens Kuhlm. A. Flower primordium, evidencing the calyx (ca), corolla (co), androecium (and), and gynoecium (gyn). B. Detail of the carpel wall (cw) enclosure. C. Establishment of the carpels, evidencing the stigma (stg), style (stl), placenta (pl), and placental column (plc). D. Carpels, with the establishment of the apical region of the septum (ap_sp), basal septum formed by the placental column, and ovular primordia (arrows). E. Detail of the ovule primordium with three evident meristematic layers: dermal (I), subdermal (II), and central (III). F. Ovular primordium, indicating the establishment of the nucellar epidermis (between white arrows), integument (black arrows), and subepidermal initials (asterisk). The arrowhead indicates the beginning of the chalazal proliferation. G. Ovular primordium with dome-shaped nucellar epidermis, integument, gynospore mother cell (asterisk), and chalazal proliferation (arrowhead). H. Detail of the gynospore mother cell (arrow). I. General view of the anatropous ovule, evidencing the dyad (asterisk) and the chalazal proliferation (arrowhead). Massive integument indicated by the black line. J. Detail of dyad cells (asterisk); cells of nucellar epidermis indicated by white arrow. K, L. Tetrad, with functional gynospore indicated by asterisk. L. under fluorescence microscopy. M. General view of the locules, evidencing the mature ovules and the chalazal proliferation (arrowheads). Scale bars $=50 \mu \mathrm{m}$ in B, E - L, $100 \mu \mathrm{m}$ in A, C, and $500 \mu \mathrm{m}$ in D, M.

proliferation in the dorsal region of the ovules, which could be characterized by cell divisions of the subdermal layer. However, cell divisions were also observed in both dermal and central layers (Fig. 2F-G). At later stages, this proliferation was characterized as a conical projection located next to the chalaza (Fig. 2I, M). 


\section{Discussion}

Floral ontogeny studies in Rubiaceae are scarce; the studies by Svoma (1991), Decraene \& Smets (2000), Groeninckx et al. (2007), and De Toni \& Mariath (2008; 2011) stand out. They are essential for interpreting morphological characteristics of the gynoecium, such as variability in the development of the carpellary septa, type of placentation and integument development, in addition to providing evolutionary evidence that clarifies taxonomic relationships.

Decraene \& Smets (2000) suggested that different types of septum morphology are important for phylogenetic studies of the Rubiaceae. In their study about ontogeny of carpels in Psychotria carthagenensis, Rudgea macrophylla, and Guettarda pohliana, Figueiredo et al. (2013a; b) observed variability in the development of septa. For $P$. carthagenensis and R. macrophylla, the authors recorded only the development of the apical septum, whereas in G. pohliana, they recorded only the development of the basal septum. The results of the present study also pointed toward this tendency of variable origins of carpellary septa. Specifically, in Dialypetalanthus fuscescens, we noticed a dual origin of the carpellary septum, in which the apical portion originated from the carpellary walls, and the basal portion originated from the placental column. These two septal regions fuse at maturity, establishing a continuous appearance. Similar observations were recorded for the genus Ixora, which presents a small apical septum and a massive basal septum (De Block 1998; De Toni \& Mariath 2008). However, in Alseis, a genus closely related to Dialypetalanthus (sensu Kainulainen et al. 2010), the ovules are attached to the apical part of the basal septum, according to Taylor (2002), while in D. fuscescens the ovules are attached in the middle part of the septum.

According to Weberling (1989), the apical septum constitutes a postgenital fusion of the dorsal faces of the carpels, which develop towards the interior of the forming locule. According to Jäger-Zürn (2011), this phenomenon occurs mainly in bicarpellate ovaries. Our study presents results that agree with the statements of both authors. Specifically, we confirm that the apical septum presents postgenital fusion of the dorsal faces of the carpels and develops towards the interior of the locule in the bicarpellate ovary of $D$. fuscescens.

In the genus Ixora, De Block (1998) described how the basal septum came from a cellular proliferation of the basal placenta. Chiurugwi et al. (2007) made a similar observation. Specifically, while assessing the placentation of Impatiens balsamina, they noticed that the massive basal septum constituted a placental column that directly originated from the floral meristem. According to Chiurugwi et al. (2007) the placenta directly originates from the floral meristem, not from the carpels, even though the placenta and the base of the carpels are connected. Based on these studies and morphological homologies with the species herein studied, it is plausible that $D$. fuscescens also originated its basal septum from the placental column. In this study we agree with Chiurugwi et al. (2007) about the independent origin of placenta and carpels. But, about the direct origin of placenta from the floral meristem we have some disagreement points. We believe that the placenta is originated from the derivatives meristematic cells of the consumed floral meristem localized in the central basal portion of the floral bud, not direct from the floral meristem. So, according of our point of view, when the differentiation of the derivatives meristematic cells originates the placenta, the process has been termed cauline placentation (Chiurugwi et al. (2007). This concept can be applied to D. fuscescens and to others Rubiaceae where placentation is considered axial, such as species of Cinchoneae and Isertieae (Robbrecht 1988), Ixora (De Block 1998), Borreria verticillata (De Toni \& Mariath 2004), and Guettarda pohliana (Figueiredo et al. 2013b). The ovules of $D$. fuscescens also develop from cauline placentation, which, again, supports the idea that is derived from derivatives meristematic cells from the floral meristem that differentiate a placenta, which originates the ovules.

The conical cellular projection in the chalazal region of the ovules, and later characterized as wings in the seeds, has restricted taxonomic distribution in Rubiaceae. It was detected in Naucleeae and Cinchoneae tribes (Robbrecht 1988), as well as D. fuscescens, analyzed herein. This structure derives from cell divisions of the subepidermal layer, which, with the development of the seed, constitutes a prominent seed wing. The morphology of the seed wing is diverse. In addition to its presence in $D$. fuscescens, this structure is strongly unilateral in species of the tribe Rondeletieae (Robbrecht 1988).

The embryological observations of $D$. fuscescens indicate a late establishment of the integument, no inclusion of the nucellus in the chalaza, dome-shaped nucellar epidermis, multiovulate placenta, and conical projection of the chalazal region, as already seen in the Ixoroideae subfamily, according Figueiredo et al. (2013 a; b). Following the more recent evolutionary diagram, as proposed by Figueiredo et al. (2013b), we observe many similarities between $D$. fuscescens and the Ixora ovule type, such as the presence of a cauline placentation, short apical septum, and dome-shaped nucellar epidermis. Other studies of the Ixoroideae taxa have highlighted these same similarities in e.g.: Coffea and Ixora (Fagerlind 1937) and Macrosphyra, Mussaenda, Scyphiphora and Tricalysia (Andronova 1977). However, in D. fuscescens, the placenta is multiovulate, while in Ixora species, the placenta is uniovulate. Moreover, $D$. fuscescens shows a conical projection of the chalaza, which becomes a wing at seed maturation. Such differences indicate that $D$. fuscescens does not fit any types of ovules mentioned by Figueiredo et al. (2013b), nor do they fit the Ixora type, as described by De Toni \& Mariath (2008). Therefore, we suggest a new ovule type: Dialypetalanthus. This type is characterized by 
the presence of a carpellary septum formed by apical and basal portions, multiovulate placenta, trizonate ovular primordium, one integument without vestiges of an external integument, dome-shaped nucellar epidermis with nonelongated cells, three to four gynospore mother cells, and conical projection of chalaza.

Apart from embryological similarities with the Ixoroideae subfamily, as previously mentioned, some morphological similarities were also observed between $D$. fuscescens and some other Ixoroideae species. For example, multiovulate carpels and seed wings, as well as tree habit, are all characteristics shared in the clade constituted by Dialypetalanthus, Bothriospora and Wittmackanthus (Kainulainen et al. 2010). This clade also shares in common interpetiolar stipules, protandrous breeding system and imbricate aestivation. Therefore, the morphological and embryological analyses performed herein add new morphological characters emphasizing the systematic studies carried out by both Bremer \& Eriksson (2009) and Kainulainen et al. (2010), which suggest the circumscription of $D$. fuscescens in the Ixoroideae subfamily.

\section{Acknowledgements}

The authors thank the Laboratório de Botânica Estrutural, Instituto de Pesquisas Jardim Botânico do Rio de Janeiro, for technical support. They also thank FAPERJ for financial support. The authors also thank Dr. Massimo Bovini, for the Figs. 1A-B, and Priscilla da Silva Coutinho, for the preparations of some slides.

\section{References}

Andronova NN. 1977. On the structure of the ovule of Rubiaceae. Botanicheskii Zhurnal 62: 1461-1469.

Bremer B, Eriksson T. 2009. Time tree of Rubiacee: phylogeny and dating the family, subfamilies, and tribes. International Journal of Plant Science 170: 766-793.

Chiurugwi T, Pouteau S, Nicholls D, Tooke F, Ordidge M, Battey N. 2007. Floral meristem indeterminacy depends on flower position and is facilitated by acarpellate gynoecium development in Impatiens balsamina. New Phytologist 173: 79-90.

Cronquist A. 1968. The evolution and classification of flowering plants. Boston, Mifflin Houghton.

De Block P. 1998. The African species of Ixora (Rubiaceae - Pavetteae). Opera Botanica Belgica 9: 1-218.

De Toni KLG, Mariath, JEA. 2004. Desenvolvimento do rudimento seminal em Borreria verticillata (L.) G. Mey. (Rubiaceae - Rubioideae - Spermacoceae). Revista Brasileira de Botânica 27: 185-192.

De Toni KLG, Mariath, JEA. 2008. Ovule ontogeny in Rubiaceae (Juss.): Chomelia obtusa (Cinchonoideae-Guettardeae) and Ixora coccinea (Ixoroideae-Ixoreae). Plant Systematic and Evolution 272: 39-48.

De Toni KLG, Mariath, JEA. 2010. Ovule ontogeny of Relbunium species in the evolutionary context of Rubiaceae. Australian Journal of Botany 58: 70-79.

De Toni KLG, Mariath, JEA. 2011. Developmental anatomy and morphology of the flowers and fruits of species from Galium and Relbunium (Rubieae, Rubiaceae). Annals of the Missouri Botanical Garden 98: 206-225.
Decraene LPR, Smets EF. 2000. Floral development of Galopina tomentosa with a discussion of sympetaly and placentation in the Rubiaceae. Systematics and Geography of Plants 70: 155-170.

Fagerlind F. 1937. Embryologische, zytologische und bestäubungsexperimentelle Studien in der Familie Rubiaceae nebst Bemerkugen über einige Polyploiditätsprobleme. Acta Horti Bergiani 2: 196-470.

Fay MF, Bremer B, Prance GT, Bank M, Bridson D, Chase MW. 2000. Plastid rbcL sequence data show Dialypetalanthus to be a member of Rubiaceae. Kew Bulletin 55: 853-864.

Figueiredo RC, Masullo FA, Vieira RC, De Toni KLG. 2013a. Development of carpels and ovules in Psychotria carthagenensis (Psychotrieae) and Rudgea macrophylla (Palicoureeae) (Rubioideae, Rubiaceae). South African Journal of Botany 84: 110-114.

Figueiredo RC, Vieira RC, De Toni KLG. 2013b. Development of the gynoecium of Guettarda pohliana in the context of Rubiaceae evolution. Botany 91: 562-567.

Gabriel BL. 1982. Biological electron microscopy. New York, Van Nostrand Reinhold.

Galati GG. 1991. Estúdios embriológicos em la tribu Spermacoceae (Rubiaceae). Parte I: Anatomia Floral. Megasporogénesis. Megagametogénesis. Boletín de la Sociedad Argentina de Botánica 27: 7-20.

Gerrits PO, Smid L. 1983. A new, less toxic polymerization system for the embedding of soft tissues in glycol methacrylate and subsequent preparing of serial sections. Journal of Microscopy 132: 81-85.

Groeninckx I, Vrijdaghs A, Huysmans S, Smets E, Dessein S. 2007. Floral ontogeny of the Afro-Madagascan genus Mitrasacmopsis with comments on the development of superior ovaries in Rubiaceae. Annals of Botany 100: 41-49.

Jäger-Zürn I. 2011. Neglected features of probable taxonomic value in Podostemaceae: The case of Polypleurum. Flora 206: 38-46.

Kainulainen K, Persson C, Eriksson T, Bremer B. 2010. Molecular systematics and morphological character evolution of the Condamineeae (Rubiaceae). American Journal of Botany 97: 1961-1981.

Kuhlmann, JG. 1925. Contribuição para o conhecimento de algumas plantas novas, contendo também um trabalho de crítica a novas combinações. Archivos do Jardim Botanico do Rio de Janeiro 4: 347-365.

Kuhlmann JG. 1942. Rubiaceae. Dialypetalanthus Kulmann. Rodriguésia 6: 25-26.

Mariath JEA, Cocucci AE. 1997. The ovules of Relbunium hypocarpium in the context of the Rubiaceae. Kurtziana 25: 141-150.

Melquior H. 1964. Engler's Syllabus der Pflanzenfamilien 2nd. edn. Berlin, Gebruder Borntraeger.

O’Brien TP, Feder N, McCully ME. 1965. Polychromatic staining of plant cell walls by Toluidine Blue O. Protoplasma 59: 368-373.

Oparka KJ, Read ND. 1994. The use of fluorescent probes for studies of living plant cells. In: Harris N, Oparka KJ. (eds.) Plant cell biology: a Practical Approach. Oxford, Oxford University Press. p. 27-50.

Piesschaert F, Robbrecht E, Smets E. 1997. Dialypetalanthus fuscescens Kuhlm. (Dialypetalanthaceae): the problematic taxonomic position of an Amazonian endemic. Annals of the Missouri Botanical Garden 84: 201-223.

Rizzini CT, Occhioni P. 1949. Dialypetalanthaceae. Lilloa 17: 243-288.

Robbrecht, E. 1988. Tropical woody Rubiaceae. Characteristic features and progressions. Contributions to a new subfamilial classification. Opera Botanica Belgica 1: 1-271.

Robbrecht, E. 1993. Advance in Rubiaceae macrosystematics. Opera Botanica Belgica 6: 1-200.

Schumann K. 1891. Rubiaceae. Pflanzenfamilien 4: 148-154.

Stebbins GL. 1974. Flowering Plants: Evolution above the species level. Cambridge, Harvard University Press.

Svoma E. 1991. The development of the bicarpellate gynoecium of Paederia L. species (Rubiaceae - Paederieae). Opera Botanica Belgica 3: 77-86.

Taylor CM. 2002. Rubiacearum Americanarum Magna Hama Pars XI. A new species of Alseis (Calycophylleae) from Central America and notes on the morphology of this neotropical genus. Novon 12: 571-574.

Wagenitz G. 1992. The Asteridae: evolution of a concept and its present status. Annals of the Missouri Botanical Garden 79: 209-217.

Weberling F. 1989. Morphology of flowers and inflorescences. Cambridge, Cambridge University Press. 